DOI https://doi.org/10.36059/978-966-397-235-0-11

\author{
Латковська Т. A., \\ orcid.org/0000-0003-3159-5994 \\ доктор юридичних наук, професор, \\ професор кафедри конституційного, \\ адміністративного та фінансового права \\ Чернівецького юридичного інституту \\ Національного університету «Одеська юридична академія», \\ м. Чернівці
}

\title{
ЗАХИСТ ПРАВ I ЗАКОННИХ ІНТЕРЕСІВ ПЛАТНИКІВ ПОДАТКІВ В УКРАЇНІ
}

Анотація. Наукове дослідження присвячено розгляду й аналізу захисту прав і законних інтересів платників податків. Зазначено, що актуальність проблеми захисту прав і законних інтересів суб'єктів правовідносин у сфері оподаткування зумовлена тим, що взаємовідносини між державою й органами місцевого самоврядування, з одного боку, і платниками податків, з іншого, спочатку складаються на засадах нерівності їх прав і законних інтересів, проте протиставляти права і законні інтереси таких суб'єктів не слід, оскільки є необхідність дотримання певного балансу прав $і$ законних інтересів публічного $i$ приватного характеру у сфері оподаткування, заснована на зацікавленості публічних утворень і платників податків один в одному, оскільки податки, збори та платежі $\epsilon$ фінансовою основою діяльності держави й органів місцевого самоврядування, що безпосередньо пов'язано з інтересами самих платників податків у зв'язку $з$ покладанням на них податкового тягаря. Конституцією Украӥни встановлено, що права та свободи людини та їх гарантії визначають зміст і спрямованість діяльності держави, яка, у свою чергу, відповідає перед людиною за свою діяльність, адже утвердження i забезпечення прав і свобод людини $\epsilon$ головним обов'язком держави. Вказано, що захист прав людини $\epsilon$ пріоритетом у діяльності держави, $і$ захист прав $i$ законних інтересів платників податків у цьому напрямі не є винятком. 
Права людини в Україні та у зарубіжних країнах: традиції та новації

\section{Вступ}

Зміна орієнтирів суспільно-політичного розвитку, перетворення й удосконалення правової сфери незмінно породжують нові ідеї. I тут досить важливо проявити гнучкість, своєчасно помітити зміни, які відбуваються, швидко й адекватно відреагувати на них. Аналізуючи сучасний стан єдиного європейського простору, здійснення соціально-політичних змін, розбудови правової держави та громадянського суспільства, відзначимо, що пріоритетним завданням $\epsilon$ не тільки переосмислення організації системи оподаткування в Україні, а й пошук шляхів іiі вдосконалення. За таких реалій вагомого значення набуває забезпечення ефективної реалізації прав платників податків на засадах рівності усіх платників перед законом, презумпції правомірності рішень платника податку, соціальної справедливості та нейтральності оподаткування. Тож висуваються особливі вимоги до всіх учасників податкових правовідносин - як зобов'язаної сторони, так і владної. Платник податків, наділений певним податковим правом, має дотримуватися правил його реалізації та не виходити за їх межі; у свою чергу, податкові органи, діючи в рамках своїх повноважень, повинні цьому сприяти. Пріоритетним напрямом держави має стати запровадження системного підходу до забезпечення прав і свобод людини, узгодженості дій органів державної влади, органів місцевого самоврядування, інститутів громадянського суспільства, суб'єктів господарювання з метою забезпечення гідного життя кожної людини в Україні, яке перебуває під охороною та правовим захистом держави.

Серед проблем Української держави, що потребують вирішення, особливе місце займають відносини щодо справляння податків, які полягають у застосуванні податкового законодавства із чіткою регламентацією дій щодо цього. Нині держава в особі органів, що формують і реалізують податкову політику в Україні, мають забезпечити функціонування відносин громадянин - держава, дотримуючись принципів публічного управління.

Податкова політика $є$ ключовим інструментом усієї державної політики, який може негативно чи позитивно впливати на економічну стабільність країни. Низький же рівень розробки податкової політики, де правила її застосування $\epsilon$ надто 
Права людини в Україні та у зарубіжних країнах: традиції та новації

складними, непростими, непередбачуваними, може викликати ефект занепаду фінансової системи загалом [1].

Незважаючи на стрімкий процес реформування в українському суспільстві, досить складно приживаються світові тенденції та налагодження партнерських взаємовідносин платників податків і контролюючих органів, які, виконуючи державне завдання із забезпечення виконання податкового обов'язку, часто ігнорують засадничі права і свободи людини та громадянина.

За умов загострення відносин між платниками податків i контролюючими органами не варто протиставляти приватних і публічних суб'єктів. Більш конструктивним буде узгодження їх інтересів, знаходження ефективних способів взаємодії, нових прогресивних податкових механізмів. Необхідна постійна та досконала перевірка ефективності наявних способів захисту прав із метою їх модернізації чи скасування, впровадження нових способів захисту права, якщо наявні не дозволяють повною мірою захистити права та законні інтереси фізичних і юридичних осіб - платників податків.

Зауважимо, що проблемам обов'язків платників податків присвячено багато досліджень, тоді як розгляд питань захисту прав і законних інтересів платників податків обмежується лише окремими статтями або параграфом у тій чи іншій науковій праці. Тож питання, пов'язані із захистом прав і законних інтересів платника податків, недостатньо досліджені в теоретичному плані.

\section{1. Конституційні основи захисту прав і законних інтересів платників податків в Україні}

Утвердження i забезпечення прав i свобод людини проголошені як обов'язок держави у ст. 3 Конституції України, тобто відразу після статті, яка має важливе значення для визначення основоположних засад становлення і розвитку української державності. Порівняно 3 Декларацією про державний суверенітет України, котра проголошувала її суверенною національною державою, ст. 1 Конституції додає до основних ознак державності такі фундаментальні характеристики, на підставі яких вона повинна будуватися як незалежна, демократична, соціальна та правова держава, тим самим збагачуючи основи конституційного ладу України та 
Права людини в Україні та у зарубіжних країнах: традиції та новації

надаючи їм системного, узгодженого характеру. Будучи розвиненою демократичною країною, українська держава взяла на себе зобов'язання щодо дотримання Міжнародного пакту про громадянські та політичні права [2]. Вищезазначене свідчить про те, що захист прав людини $є$ пріоритетом у діяльності держави, i захист прав платників податків у цьому напрямі не $\epsilon$ винятком.

Усі зміни, які відбуваються у податковій сфері, мають відповідати засадничому положенню - узгодженню та поєднанню інтересів платників податків і податкових органів, а отже, грунтуватися на співмірності приватного та публічного інтересів. Розмитість меж між приватними та публічними інтересами в оподаткуванні демонструє трансформацію суспільних або державних інтересів в інтереси приватного характеру та навпаки. У правовій державі має панувати принцип координації та гармонізації публічних і приватних інтересів [3]. Виконання зазначених умов $\epsilon$ запорукою ефективної реалізації прав платників податків. Забезпечення правового регулювання, спрямованого на ефективне справляння податків із суб'єктів господарювання, яке враховує процеси міжнародних економічних відносин, що ускладнилися й інтенсифікувалися, $\epsilon$ викликом для сучасної соціальної та правової держави. Потрібно пам'ятати, що основне завдання держави полягає у створенні такої системи права, де б враховувалися інтереси всіх учасників суспільних відносин.

Захист прав платників податків і їх гарантованість $\epsilon$ запорукою розвитку економіки країни та їі промислового потенціалу, сприяючи залученню внутрішніх і зовнішніх інвестицій. Ступінь довіри суспільства до держави визначається дотриманням посадовими особами державних органів норм права і його основоположних принципів, особливо, коли питання захисту виникають під час проведення податкового контролю, де співробітники фіскального органу наділені владними повноваженнями. У цьому випадку питання довіри стоїть найгостріше.

Податки, що мають на меті забезпечення публічних інтересів, сьогодні $\epsilon$ необхідним економічним підгрунтям існування держави, формуючи доходну частину бюджету, а обов'язок сплачувати податки і збори в порядку й у розмірах, установлених законом, поширюється на всіх платників як обов'язкова вимога, 
Права людини в Україні та у зарубіжних країнах: традиції та новації

закріплена у ст. 67 Конституції України, прийнятої у червні 1996 p. [4].

Аналіз змісту правовідносин у сфері оподаткування показує, що фіскальні (податкові) органи в рамках захисту державних інтересів, володіючи щодо платників податків владними повноваженнями, забезпечують виконання ними обов'язків зі сплати обов'язкових платежів, однак застосовувати до таких суб'єктів забезпечувальні заходи слід у тих межах, у яких це необхідно державі й органам місцевого самоврядування для захисту своїх податкових прав і законних інтересів.

Незважаючи на наявність можливості у владної сторони, здійснюючи податковий контроль, впливати на поведінку та волю підпорядкованої сторони, орган влади, уповноважений із контролю і нагляду у сфері податків і зборів, не може впливати на зміну норми, встановлену законом. Податковий орган зобов'язаний дотримуватися прав платника податків i не перешкоджати, а точніше забезпечувати можливість їх реалізації, що, у свою чергу, дозволяє дотримати баланс приватного i публічного інтересу. У правовідносинах податкового контролю сторони рівні перед законом. Зауважимо, що питання про захист прав платника податків у ході податкового контролю становить інтерес як для правової науки, так і для юридичної практики.

Відносини між громадянином i державою регулюються Конституцією України, яка стала важливим політико-правовим актом, що стабілізував незалежний розвиток України як у внутрішніх, так і зовнішніх відносинах. Конституція відіграє свою особливу роль як Основний Закон держави та суспільства. Водночас після прийняття Конституції почали виявлятися ії вади, котрі, зокрема, стосувалися не тільки організації державної влади, але й гармонізації відносин між державою, громадянським суспільством і людиною.

Вчені-конституціоналісти зазначали про відставання у реформуванні конституційних засад організації державної влади та забезпечення прав і свобод людини, звертаючи увагу на такі загальнометодологічні засади реформування Конституції України [5]:

по-перше, це принцип системності та комплексності у модернізації Основного Закону. На підставі змін, що відбулися у суспільно-політичному житті, оновленню підлягали фактично усі розділи Конституції та її преамбула, які знаходилися у відповідній 
системі. У процесі реформування, як відзначав Ю.С. Шемшученко, може збільшитися кількість статей Конституції, але Конституція України, за винятком Португалії, $\epsilon$ найбільшою у європі. Хоча у світі $\epsilon$ і більші Конституції, які нагадують кодекси (Індія - 325, Таїланд 309, Бразилія - 250 статей). Вчений підкреслював, що Конституція України має бути лаконічною і зрозумілою для широкого загалу, національною за формою i цивілізаційною за змістом, наголошуючи, що це пов'язано із системним підходом до оновлення Основного Закону, посиленням наукового обгрунтування, адже дійсно, у державі без науки немає майбутнього;

по-друге, важливим принципом $є$ принцип народовладдя, який передбачає побудову системи соціальних цінностей таким чином, щоб на її вершині була людина. Цей принцип зафіксований у ст. 5 Конституції України, де закріплено, що носієм суверенітету та єдиним джерелом державної влади $\epsilon$ народ України.

Розуміючи, що народ $є$ спільнотою, котра складається 3 пов'язаних спільним громадянством індивідів, що мають первинні щодо держави права, відповідно до преамбули Конституції України державоутворююча українська нація розглядається як складова частина українського народу [6, с. 34].

Вченими звертається увага на доцільність конституювати інститут громадянського суспільства. Мається на увазі посилення впливу громадянського суспільства на стан і характер функціонування публічної влади. Це й конституційне закріплення прав громадян на законодавчу ініціативу, здійснення громадського контролю за діяльністю органів державної влади та органів місцевого самоврядування. Виникає потреба у передбаченні додаткових конституційних гарантій для забезпечення прав і свобод громадян, зокрема, конституційної норми про недопущення звуження змісту та обсягу існуючих прав і свобод при прийнятті нових законів (ст. 22 Конституції). Однак і сьогодні спостерігаємо порушення цієї конституційної норми, коли відбувається систематичне реформування податкової законодавчої бази, коли безсистемно вносяться зміни до Податкового кодексу, ускладнюючи податкове навантаження на платників податків. Незважаючи на внесення суттєвих змін кожного року до Податкового кодексу України, діюча податкова система України не забезпечує збалансованого 3 реальними можливостями економіки податкового навантаження на суб'єктів 
Права людини в Україні та у зарубіжних країнах: традиції та новації

господарювання, іiї реформування викликає необхідність невідкладної стабілізації фінансової ситуації, стимулювання процесів економічного зростання та підвищення інвестиційної привабливості України на міжнародній арені загалом.

По-новому оцінити роль і завдання державної влади дозволяє аналіз її крізь призму людини, її прав і потреб. Всі основні цілі, які висуваються сьогодні до владних інститутів (створення, підтримання і забезпечення добробуту громадян, їх прав і свобод, задоволення соціальних потреб та інтересів, забезпечення суспільного порядку i безпеки, державне регулювання економічного, соціального, культурного і національного життя тощо) можуть бути представлені як способи забезпечення універсальної мети, якою $є$ забезпечення прав людини. Тому, оцінюючи державне управління з позицій забезпечення прав людини, можна не лише визначити його гуманістичну спрямованість та ефективність, а й представити його як складну, впорядковану, ціннісно орієнтовану діяльність чисельних органів державної влади, яких поєднує спільна мета [5, с. 12].

Захист прав платників податків і їх гарантія $\epsilon$ запорукою розвитку економіки української держави. Недостатньо такий захист прописати у законі, головне, щоб такий захист був ефективним. Рішення, які стосуються захисту прав платників податків, необхідно приймати у найкоротші терміни, а правова позиція має бути максимально вичерпною.

Право на захист розглядають в об'єктивному та суб'єктивному розумінні. В об'єктивному розумінні - це юридичний інститут, що включає сукупність правових норм, які регулюють відносини, пов'язані із захистом прав платника податків, і включає як матеріально-правові, так і процесуальноправові норми. У суб'єктивному розумінні право платника податків на захист $\epsilon$ вибором можливості певної поведінки суб'єкта захисту, дозволеного чинним законодавством.

Право на захист і власне захист тісно взаємопов'язані між собою. Захист є результатом реального здійснення (реалізації) відповідного права. Поняття захисту ширше, ніж відповідне право. Результату завжди передують певні дії суб'єкта, що використовує засоби та способи захисту, а також права на їх реалізацію i застосування. Зазвичай захист виступає узагальненим поняттям і передбачає, зокрема, право на захист. 
Цілями захисту прав платника податків $є$ : попередження можливих правопорушень, припинення протиправних дій, усунення перешкод у здійсненні суб'єктивних прав, відновлення порушених прав, справедливості та законності, а також усунення загрози їх порушення або оспорювання.

Розглядаючи механізм як сукупність засобів, способів, методів, спрямованих на рішення відповідної проблеми (завдання), зазначимо, що механізм означає внутрішній устрій, сукупність станів і процесів, які складають будь-яке явище, пристрій для передачі та перетворення, що становить систему тіл (ланок), у якій рух одного або декількох тіл (ведучих) викликає рух інших тіл системи [7, с. 415]. Під механізмом правового регулювання розуміється система специфічних правових засобів (інструментів), за допомогою яких упорядковують суспільні відносини, реалізуються позитивні інтереси суб'єктів права та досягаються цілі правового регулювання [8, с. 283]. Під механізмом захисту прав платників податків розуміється система правових та організаційних засобів, закріплених законодавством, функціонування яких спрямоване на забезпечення адекватного обмеження майнових прав платника податків [9].

Наочно механізм захисту ілюструє іiї процедурнопроцесуальний аспект, але це не означає, що до матеріальноправового він не має відношення [10].

Преамбула Конституції, а ії положення мають істотне значення в соціальному, політичному, ідеологічному та юридичному аспектах, стисло визначає цілі, задля досягнення яких приймається Конституція, серед яких - забезпечення прав i свобод людини та гідних умов іiї життя. Саме така ціль визначає цінності, які посідають чільне місце в усій ієрархії суспільних цінностей, а тому слушно вважається загальнолюдською та загальноцивілізаційною.

3 метою подальшого удосконалення діяльності щодо утвердження та забезпечення прав i свобод людини та громадянина в Україні відповідно до ст. 102 Конституції України указом Президента було затверджено Національну стратегію у сфері прав людини_[11].

У Стратегії зазначено, що події Революції Гідності (листопад 2013 - лютий 2014 рр.) засвідчили незворотне прагнення Українського народу до побудови правової та демократичної 
Права людини в Україні та у зарубіжних країнах: традиції та новації

держави, у якій гарантуються та забезпечуються права і свободи людини. Тож затвердження Національної стратегії у сфері прав людини зумовлено необхідністю вдосконалення діяльності держави щодо утвердження та забезпечення прав і свобод людини, створення дієвих механізмів їх реалізації та захисту, розв'язання системних проблем у зазначеній сфері. Все це має пряме відношення до захисту прав і законних інтересів платників податків.

Стратегія зосереджена на розв'язанні основних системних проблем у сфері забезпечення, реалізації та захисту прав і свобод людини за умов нових викликів, що постали перед суспільством, але не вичерпує повністю проблематики у зазначеній сфері.

Удосконалення системи забезпечення та захисту прав і свобод людини має здійснюватися 3 урахуванням як вітчизняного досвіду, так і напрацьованих та апробованих міжнародною спільнотою принципів і підходів. У зв'язку з цим повинно бути взято до уваги й активно використано досвід Уповноваженого Верховної Ради України з прав людини, Європейського Союзу, Організації Об'єднаних Націй, Ради Європи, Організації з безпеки і співробітництва у Європі, інших міжнародних організацій, практику Європейського суду 3 прав людини, досвід правозахисних організацій України.

Результатом реалізації Стратегії має стати запровадження системного підходу до забезпечення прав і свобод людини, узгодженості дій органів державної влади, органів місцевого самоврядування, інститутів громадянського суспільства, суб'єктів господарювання, створення в Україні ефективного механізму реалізації та захисту прав і свобод людини, усунення недоліків системного характеру, які лежать в основі порушень, виявлених Європейським судом.

Економічні права та свободи займають важливе місце у системі конституційних прав і свобод людини та громадянина. Вони визначають можливість людини створювати матеріальні й особисті нематеріальні блага, володіти ними та здійснювати господарську діяльність. Конституція України містить порівняно незначну кількість основних економічних прав і свобод, до яких відносять: право приватної власності (ст. 41); право на підприємницьку діяльність, яка не заборонена законом (ст. 42); право на користування об'єктами права державної та комунальної власності (ст. 41) та власністю Українського народу 
Права людини в Україні та у зарубіжних країнах: традиції та новації

(ст. 13). Утім, ці конституційні права комплексно розвинулися у чинному законодавстві України.

Отже, економічні права та свободи людини і громадянина - це нормативно визначена міра можливої поведінки або діяльності людини та громадянина в економічній сфері суспільних відносин, пов'язана із правовим режимом власності та господарської діяльності.

Первинним, базисним економічним правом, яке визначає економічні основи суспільного і державного ладу України, $\epsilon$ право володіти, користуватися i розпоряджатися своєю власністю, результатами своєї інтелектуальної, творчої діяльності (с. 41), що набувається в порядку, визначеному чинним законодавством України. Об'єктами права приватної власності визначаються матеріальні (рухомі та нерухомі) й особисті нематеріальні цінності (блага). Формою здійснення правовідносин, пов'язаних із реалізацією права приватної власності, $\epsilon$ володіння, користування i розпорядження матеріальними й особистими нематеріальними цінностями (благами) з метою задоволення соціально-економічних потреб людини та громадянина.

Водночас Основний Закон застерігає, що власність зобов'язує не завдавати шкоди правам, свободам і гідності громадян, інтересам суспільства, не погіршувати екологічну ситуацію i природні якості землі. Тобто використання права приватної власності для завдання шкоди та збитків іншим особам і їх законним правам, а також на шкоду інтересам суспільства та держави $\epsilon$ неприпустимим.

Держава гарантує, що ніхто не може бути протиправно позбавлений власності та декларує непорушність права приватної власності. Примусове відчуження об’єктів права приватної власності може бути застосоване лише як виняток із мотивів суспільної необхідності, на підставі й у порядку, встановлених законом, за умови попереднього i повного відшкодування їх вартості. Примусове відчуження таких об'єктів із подальшим повним відшкодуванням їх вартості допускається лише за умов воєнного чи надзвичайного стану. Тож націоналізація та реприватизація об'єктів права приватної власності є неконституційною. 
Конфіскація як форма відчуження приватної власності може застосовуватися лише за рішенням суду, як додаткова санкція в адміністративній і кримінальній юридичній відповідальності.

Наступним важливим економічним правом $\epsilon$ право кожного на підприємницьку діяльність, яка не заборонена законом (ст. 42). За змістом це право дозволяє здійснювати на свій ризик діяльність, що передбачає отримання прибутку; за суб'єктами це право належить всім громадянам України, іноземцям і особам без громадянства, за винятком депутатів, посадових і службових осіб органів державної влади й органів місцевого самоврядування, військовослужбовців, співробітників правоохоронних органів, суддів та ін.

Коли бюрократичний апарат, реалізуючи свої регулюючі функції, з метою підтримки конкурентності ринків стає більш активно втручатися в економіку за умов повного домінування однієї гілки влади у країні та відсутності гарантій законності, зокрема захисту прав приватної власності, це призводить до вкрай негативних наслідків.

Держава забезпечує захист конкуренції у підприємницькій діяльності, упереджує зловживання монопольним становищем на ринку, неправомірне обмеження конкуренції та недобросовісну конкуренцію. Зокрема, в Україні діє Антимонопольний комітет України, метою діяльності якого $є$ забезпечення державного захисту конкуренції у підприємницькій діяльності й у сфері публічних закупівель [12]. Основним завданням Антимонопольного комітету України $€$ участь у формуванні та реалізації конкурентної політики в частині:

1) здійснення державного контролю за дотриманням законодавства про захист економічної конкуренції на засадах рівності суб'єктів господарювання перед законом і пріоритету прав споживачів, запобігання, виявлення і припинення порушень законодавства про захист економічної конкуренції;

2) контролю за узгодженими діями суб'єктів господарювання та дотриманням вимог законодавства про захист економічної конкуренції під час регулювання цін (тарифів) на товари, що виробляються (реалізуються) суб'єктами природних монополій;

3) сприяння розвитку добросовісної конкуренції; 
Права людини в Україні та у зарубіжних країнах: традиції та новації

4) здійснення контролю щодо створення конкурентного середовища та захисту конкуренції у сфері публічних закупівель;

5) проведення моніторингу державної допомоги суб'єктам господарювання та здійснення контролю за допустимістю такої допомоги для конкуренції та ін.

Конституція України також покладає на державу обов'язок захищати права споживача, здійснювати контроль за якістю і безпечністю продукції та усіх видів послуг і робіт, сприяти діяльності громадських організацій споживачів. Тобто держава забезпечує соціальний характер підприємницької діяльності в Україні.

Похідним від права власності $€$ й право громадян України користуватися об'єктами права державної та комунальної власності для задоволення своїх потреб (ч. 3 ст. 41) та власністю Українського народу (ст. 13), але це право є лише різновидом права власності та потребує свого законодавчого закріплення і належного теоретичного обгрунтування.

Реалізація в Україні адміністративної, податкової та судовоправової реформ посилює увагу як науковців, так і практиків до публічно-правових відносин, у т. ч. до питань, що пов'язані із захистом прав, свобод і законних інтересів людини та громадянина.

Функціонування Податкового кодексу України та нормативно-правових актів, які регламентують порядок застосування його матеріальних норм, показало, що його правові приписи потребують змін у процесі їх застосування.

Взаємовідносини людини та держави у сфері справляння податків сьогодні $є$ дещо напруженими і нерідко зумовлюють виникнення конфліктних ситуацій між платниками податків, 3 одного боку, і державою в особі податкових органів, з іншого.

Складність вирішення таких суперечностей полягає в тому, що нині чинне законодавство не достатньою мірою унормувало процеси розв'язання конфліктних ситуацій, які виникають між платниками податків i податковими органами держави, їx посадовими та службовими особами.

Проблемність захисту прав платників податків у сфері справляння податків полягає в тому, що у цьому процесі домінуюча роль відводиться податковим органам, які зобов'язані здійснювати фіскальну функцію по наповненню бюджетів усіх рівнів. 


\section{2. Податкова система та важливість захисту прав платників податків}

Трансформаційні процеси, які відбуваються в економіці України, істотно відбиваються на податковій системі держави загалом. Податкова система як сукупність податків і зборів, що справляються на території держави, а також правил встановлення, введення та справляння таких податків і зборів показує рівень розвитку економіки. Призначення податкової системи, яка $\epsilon$ органічною складовою частиною економічної моделі розвитку країни, полягає не лише у встановленні, введенні, справлянні податків і забезпеченні доходної частини бюджету для виконання державою своїх функцій, а й у сприянні досягненню стратегічної мети розвитку національної економіки.

Сучасний суперечливий стан економіки вимагає пошуку принципово нових підходів до їі управління. Перехідні процеси зазвичай виявляються неоднозначними та досить складними. Відчутні помилки, допущені на перших етапах переходу до ринкової економіки, призвели до негативних наслідків і перекосів в економічному розвитку країни.

у сучасному світі жодна із країн не ставить під сумнів необхідність оподаткування, враховуючи виняткове значення податків, зборів, платежів як джерела формування бюджетів, інших публічних фондів коштів, дбаючи про захист прав i законних інтересів платників податків. Україна як країна 3 ринковою економікою намагається сформувати таку податкову систему, яка була би спроможна забезпечити фінансові потреби держави й органів місцевого самоврядування, не порушуючи права та законні інтереси платників податків.

Відомо, що основним державним інструментом регулювання суспільних відносин виступає податкова політика як один із основних напрямів фінансової діяльності держави, що здійснюється уповноваженими органами державної влади з метою мобілізації грошових коштів у формі податків, зборів, платежів до бюджетних фондів, адже і податки, і збори, і платежі $є$ необхідною ланкою економічних відносин у суспільстві з моменту виникнення державності. Розвиток i зміна державного устрою завжди супроводжувалися перетворенням податкової системи, однак зрозуміло, що ідеальну податкову систему можна створити тільки на серйозній теоретичній основі шляхом розроблення та впровадження нових ефективних підходів у податково-правовому 
Права людини в Україні та у зарубіжних країнах: традиції та новації

регулюванні, враховуючи специфіку економічних відносин у суспільстві та створений науковий і виробничий потенціал. Можливості фінансової стабілізації, стан доходної частини бюджету зазвичай залежать від багатьох складників, серед яких і загальна ситуація в економіці, особливо у базових ії галузях, i, що важливо, стан податкової системи країни.

Податкова система $\epsilon$ багатоаспектною категорією, яка досліджується представниками як юридичної, так і економічної науки. Законодавець визначає податкову систему як сукупність загальнодержавних і місцевих податків і зборів, що справляються в установленому Податковим Кодексом порядку [13].

Існує думка, що податкова система держави - це складне та багатогранне явище, яке формується під дією об’єктивних факторів (пов'язано з об'єктивним характером існування власне самих податків як економічної категорії) та суб'єктивних факторів (пов'язано з тим, що податкова система $є$ похідним елементом і проявом на практиці податкової політики, яка проводиться у тій чи іншій країні та формується відповідними державними структурами через податкове право і податкове законодавство) [14, с. 3]. Важливим інструментом для розвитку податкової системи $є$ податкова політика держави, саме тому питанням реалізації державної податкової політики приділяється значна увага, особливо за умов фінансової децентралізації.

Податкову систему розглядають як засновану на певних принципах систему врегульованих нормами права суспільних відносин, що складаються у зв'язку зі встановленням і справлянням податків і зборів. До складу цієї системи належать не лише податкові платежі, у зв'язку зі сплатою яких виникають зазначені відносини, але також оподатковувані суб'єкти, тобто особи, на користь яких сплачуються податки та збори, податкові (фінансові, митні) органи, органи державних позабюджетних фондів, податківці, органи внутрішніх справ, платники податків, платники зборів, податкові агенти та деякі ін. Усі ці елементи перебувають у постійному та нерозривному взаємозв'язку [15, с. 71].

Податкову систему визначають і як взаємопов'язану сукупність всіх наявних у державі суспільних відносин, що складаються у сфері оподаткування i мають економічний, політичний, організаційний і правовий характер; як сукупність встановлених у державі істотних умов оподаткування; як сукупність податків, 
зборів, мит йта інших обов'язкових платежів до бюджетів різних рівнів і державні позабюджетні фонди, які встановлені на принципах i в порядку, визначених законами. В останньому визначенні робиться акцент на об'єднанні в податкову систему країни різних обов'язкових платежів податкового характеру, конкретні види і склад яких залежать від особливостей тієї або іншої держави та їі національного податкового законодавства, котре, у свою чергу, і $є$ засобом упорядкування різних податкових платежів у єдину податкову систему.

Водночас низка вчених висловлює думку щодо можливості розширеного тлумачення змісту поняття податкової системи. Наприклад, М.П. Кучерявенко зазначає, що «у широкому сенсі податкова система $\epsilon$ сукупністю податків, зборів і платежів, законодавчо закріплених у державі; принципів, форм і методів їх встановлення, зміни або скасування; дій, які забезпечують їх сплату, контроль і відповідальність за порушення податкового законодавства» $[16$, с. 55]. Л.К. Воронова підкреслює, що при визначенні податкової системи важливо розрізнювати два підходи їі розуміння. Так, з одного боку, податкова система $\epsilon$ сукупністю податків і зборів, виступаючи механізмом визначених, законодавчо закріплених важелів із акумуляції доходів держави, - у цьому випадку робиться акцент на матеріальній стороні податкової системи, що забезпечує механізм дії податків, і вона збігається із системою податків і зборів. 3 іншого боку, податкова система містить і «достатньо широкий спектр процесуальних відносин зі встановлення, зміни та скасування податків, зборів, платежів, забезпечення їх сплати, організації контролю і відповідальності за порушення податкового законодавства. Це немов би тіньова, але не менш важлива частина податкової системи» [17, с. 125].

Тому не слід змішувати поняття «система податків» із поняттям «податкова система». Податкова система - це сукупність встановлених у державі істотних умов оподаткування. Істотними умовами оподаткування, що характеризують податкову систему, є: принципи оподаткування; порядок встановлення та введення податків; система податків; порядок розподілу податкових надходжень між бюджетами різних рівнів; права й обов'язки учасників податкових правовідносин; форми та методи податкового контролю; відповідальність учасників податкових правовідносин; способи захисту прав та інтересів учасників 
податкових правовідносин. Поняття «податкова система» характеризує податковий правопорядок загалом, а система податків - тільки елемент податкової системи [18, с. 262].

Американський економіст Р. Масгрейв сформулював основні вимоги до функціонування податкової системи:

1) розподіл податкового тиску повинен бути рівномірним;

2) мінімальний тиск на економічні рішення; будь-яке державне втручання, пов'язане 3 «надмірним оподаткуванням», слід зменшити;

3) якщо перед податковою політикою поставлено інші цілі, наприклад, стимулювання інвестицій, звести до мінімуму можливе порушення рівноваги між соціальною справедливістю й економічною ефективністю;

4) сприяти стабілізації економіки й економічному росту;

5) оподаткування має бути зрозумілим для платника податків, а управління ним - справедливим і основаним на законах;

6) витрати на управління податковою системою мають бути мінімальними [2, с. 100].

Якщо дотримуватися вказаних вимог, то виникає питання: а як вони діють у нашій країні? М.П. Кучерявенко також зауважує, що такий підхід настільки розширено характеризує податкову систему, що практично позбавляє це поняття властивих їй особливостей [19, с. 458-459]. Податкова система, будучи складовою частиною системи оподаткування, грунтується на конкретних принципах, а суспільні відносини, які регулюються нормами права, виникають при нарахуванні, утриманні та перерахуванні до бюджету податків, зборів, платежів. Саме ці основні особливості визначають специфіку цих відносин, визначають коло суб'єктів відносин і визначають межі у розмежуванні таких складних взаємопов'язаних понять, як «податкова система» та «система оподаткування». Податкова система виступає лише складовою частиною системи оподаткування.

До елементів податкової системи відносять зазвичай податкове законодавство; принципи оподаткування; систему податкових платежів; склад учасників податкових відносин, їх правовий статус; систему органів податкового адміністрування; форми та методи податкового контролю; відповідальність за 
порушення податкового законодавства; засоби захисту прав та інтересів учасників податкових відносин [20, с. 217].

На жаль, сучасна податкова система України зберігає низку недоліків і, на відміну від країн Європейського Співтовариства, не $є$ інструментом підвищення конкурентоспроможності держави.

12 січня 2015 р. Президентом України був підписаний Указ «Про Стратегію сталого розвитку «Україна-2020» [21]. Стратегія визначає цілі, напрями, пріоритети розвитку країни, а також містить 25 ключових показників, за якими буде оцінюватися перебіг виконання реформ і програм. Метою реформ було задекларовано досягнення європейських стандартів життя та гідного місця Україні у світі. У перспективному розвитку країни визначено чотири основні вектори:

1) вектор розвитку - забезпечення сталого розвитку держави, проведення структурних реформ i, як наслідок, підвищення стандартів життя. Україна має стати державою із сильною економікою та з передовими інноваціями;

2) вектор безпеки - забезпечення гарантій безпеки держави, бізнесу та громадян, захищеності інвестицій і приватної власності;

3) вектор відповідальності - це забезпечення гарантій, що кожен громадянин, незалежно від раси, кольору шкіри, політичних, релігійних та інших переконань, статі, етнічного й соціального походження, майнового стану, місця проживання, мовних або інших ознак, матиме доступ до високоякісної освіти, системи охорони здоров'я та інших послуг у державному та приватному секторах;

4) вектор гордості - забезпечення взаємної поваги та толерантності у суспільстві, гордості за власну державу, іiі історію, культуру, науку, спорт.

У рамках названих чотирьох векторів руху «Стратегія-2020» включає у себе 62 реформи. 3 них пріоритетними визначено вісім реформ і дві програми. У документі уточняється, що кількість і зміст названих реформ і програм розвитку держави можуть змінюватися у процесі реалізації.

Серед реформ було наголошено і на податковій реформі, метою якої $\epsilon$ побудова податкової системи, яка $\epsilon$ простою, економічно справедливою, з мінімальними затратами часу на розрахунок і сплату податків, створює необхідні умови для сталого розвитку національної економіки, забезпечує достатнє наповнення 
Права людини в Україні та у зарубіжних країнах: традиції та новації

Державного бюджету України та місцевих бюджетів. Головними напрямами реформи Стратегією визначаються: перехід від наглядово-каральної функції фіскальних органів до обслуговуючої, що допомагає у нарахуванні та проведенні сплати податків, а не має на меті наповнення бюджету за рахунок фінансових санкцій і переплат; зменшення кількості податків, їх розміру та спрощення порядку розрахунку і сплати; впровадження електронних сервісів для платників податків; зменшення податкового навантаження на заробітну плату 3 метою іiї детінізації; удосконалення законодавства України, спрямованого на посилення боротьби зі схемами ухиляння від сплати податків як юридичними, так і фізичними особами, зокрема удосконалення адміністрування податку на додану вартість, формування системи податкового контролю залежно від ступеня ризику в діяльності платників податків, забезпечення відкритості доступу до інформації про сплату податків, удосконалення законодавства 3 питань трансфертного ціноутворення, впровадження контролю за видатками фізичних осіб.

У розвинутих європейських країнах податкові реформи спрямовані на лібералізацію системи оподаткування 3 метою запобігання відтоку капіталу і кваліфікованих спеціалістів. В Україні реформаційні процеси в перебудові податкової системи за останні роки не мають сталого характеру, безсистемно врегульовуються окремі питання, а запроваджені зміни орієнтовані на нетривалі терміни часу. Незважаючи на внесення щороку суттєвих змін до Податкового кодексу України, чинна податкова система України не забезпечує збалансованого з реальними можливостями економіки податкового навантаження на суб'єктів господарювання, iї реформування викликане необхідністю невідкладної стабілізації фінансової ситуації, стимулювання процесів економічного зростання та підвищення інвестиційної привабливості України на міжнародній арені загалом.

Сучасне податкове законодавство України зберігає низку суттєвих недоліків, які $€$ системними: значну колізійність підзаконних нормативно-правових актів, які регулюють податкові відносини; нестабільність податкового законодавства, а саме численні зміни до Податкового кодексу України; наявність законів, що належать до інших галузей права, але регулюють податкові відносини. Всі ці проблеми вказують на недосконалість і неефективність чинної податкової системи, на 
Права людини в Україні та у зарубіжних країнах: традиції та новації

те, що вона не сприяє економічному зростанню країни, а захист прав платників податків заслуговує на краще.

Відомо, що податкове законодавство України $\epsilon$ одним із найскладніших у правовій системі України. Стабільність податкового законодавства $є$ однією з основних вимог під час вибору інвесторами країни для вкладення інвестицій, про необхідність залучення яких постійно говорять представники різних гілок влади в Україні. Законодавець повинен гарантувати стабільність податкової політики, що, у свою чергу, стимулюватиме інвестора у процесі ухвалення рішення.

Значна частота внесення змін до Податкового кодексу України не тільки істотно ускладнює роботу контролюючих органів із забезпечення виконання платниками податків податкових зобов'язань, а й негативно позначається на діяльності суб'єктів підприємництва, зокрема внаслідок обмежених можливостей щодо формування їх власної політики.

Сучасний стан податкового законодавства $\epsilon$ дуже суперечливим і потребує вдосконалення, проте, як показує практика його правозастосування, зміни, що вносяться до законодавства 3 питань оподаткування, досить часто спричиняють нові проблеми, адже багато норм суперечать одна одній або ж їх просто неможливо втілити у життя.

Відповідно до Указу Президента Кабінет Міністрів України має щороку до 15 лютого затверджувати план дій щодо реалізації положень Стратегії та щоквартально інформувати про стан виконання плану дій щодо реалізації положень Стратегії. Президент наголосив на тому, що українська держава $\epsilon$ парламентсько-президентською, а не президентськопарламентською республікою, а це означає, що тональність економічної політики держави все таки визначає Кабінет Міністрів України.

Чи буде виконана податкова реформа (Стратегією передбачена реалізація 12 реформ на рік) - покаже час. Сьогодні перед країною стоїть надзвичайно відповідальне завдання виходу з економічної кризи. Які реформи ми спроможні провести на належному рівні, щоб виконати мету Стратегії, котра передбачає досягнення європейських стандартів життя та гідного місця України у світі? Як буде здійснюватися захист прав і законних інтересів платників податків? Покаже час. 
Права людини в Україні та у зарубіжних країнах: традиції та новації

Модернізація податкової системи України почалася ще 3 моменту отримання країною незалежності. Важливими чинниками були наміри збільшити доходи до бюджету, усунути певні прогалини у податковому законодавстві, зменшити податкове навантаження.

Ще до отримання незалежності нашої країни діяв Закон УРСР «Про систему оподаткування», прийнятий у 1991 р., яким визначався перелік загальнореспубліканських податків, зборів та обов'язкових платежів. У 1997 р. було прийнято нову редакцію Закону «Про систему оподаткування» 3 новим складом загальнодержавних податків і зборів (обов'язкових платежів), таких як: податок на додану вартість; акцизний збір; податок на прибуток підприємств; податок на доходи фізичних осіб; мито; державне мито; податок на нерухоме майно (нерухомість); плата (податок) за землю; рентні платежі; податок із власників транспортних засобів та інших самохідних машин і механізмів; податок на промисел; збір за геологорозвідувальні роботи, виконані за рахунок державного бюджету; збір за спеціальне використання природних ресурсів; збір за забруднення навколишнього природного середовища; збір до Фонду для здійснення заходів щодо ліквідації наслідків Чорнобильської катастрофи та соціального захисту населення; збір на обов'язкове соціальне страхування; збір на обов'язкове державне пенсійне страхування; збір до Державного інноваційного фонду; плата за торговий патент на деякі види підприємницької діяльності. Встановлений був і перелік місцевих податків і зборів (обов'язкових платежів): податок із реклами; комунальний податок; готельний збір; збір за припаркування автотранспорту; ринковий збір; збір за видачу ордера на квартиру; курортний збір; збір за участь у бігах на іподромі; збір за виграш на бігах на іподромі; збір з осіб, які беруть участь у грі на тоталізаторі на іподромі; збір за право використання місцевої символіки; збір за право проведення кіно- і телезйомок; збір за проведення місцевого аукціону, конкурсного розпродажу і лотерей; збір за проїзд по території прикордонних областей автотранспорту, що прямує за кордон; збір за видачу дозволу на розміщення об’єктів торгівлі та сфери послуг; збір із власників собак.

Принципово змінюється ситуація із прийняттям у 2010 р. Податкового Кодексу України [13], який складається 3 норм, котрі охоплюють регулювання всіх найважливіших відносин у 
Права людини в Україні та у зарубіжних країнах: традиції та новації

сфері оподаткування. Податковий Кодекс України виступає головним законодавчим актом, що регулює відносини оподаткування, податкову систему, i основи, елементи правового механізму податку. У Податковому Кодексі поєднуються матеріальні та процесуальні сторони регулювання податкової системи, всі аспекти справляння податків і зборів.

Відповідно до норм Податкового Кодексу до загальнодержавних податків належать: податок на прибуток підприємств; податок на доходи фізичних осіб; податок на додану вартість; акцизний податок; екологічний податок; рентна плата; мито.

До місцевих податків належать: податок на майно (складається 3 податку на нерухоме майно, відмінне від земельної ділянки; транспортного податку; плати за землю); єдиний податок. До місцевих зборів належать: збір за місця для паркування транспортних засобів; туристичний збір.

Податковий кодекс України, регулюючи відносини, що виникають у сфері справляння податків і зборів, визначає вичерпний перелік податків і зборів, які справляються в Україні, та порядок їх адміністрування, платників податків і зборів, їх права й обов'язки, компетенцію контролюючих органів, повноваження й обов'язки їх посадових осіб під час адміністрування податків і зборів, а також відповідальність за порушення податкового законодавства.

Реформування податкової системи відобразилося і на значних змінах до норм Податкового кодексу. Так, із початку прийняття Податкового кодексу Верховною Радою (2 грудня 2010 р., а вступив він у дію 1 січня 2011 р.) прийнято 155 законодавчих актів, якими були внесені зміни до Кодексу.

На підставі Указу Президента України 24 грудня 2012 р. відбулася реорганізація Державної митної служби України та Державної податкової служби України, їх об'єднання у єдиний орган - Міністерство доходів і зборів України, яке було створене як центральний орган виконавчої влади. У цей період податкова система була перетворена на фіскальну систему 3 подвійним оподаткуванням, що створило умови для тіньової системи оподаткування української економіки, однак Міністерство доходів і зборів України проіснувало недовго, і вже 1 березня 2014 р. було ліквідовано.

У 2014 р. наступним кроком реформування податкової системи було утворення Державної фіскальної служби замість 
Права людини в Україні та у зарубіжних країнах: традиції та новації

Міністерства доходів і зборів, котра була вже підпорядкована Міністерству фінансів, а їі діяльність спрямовувалася та координувалася Кабінетом Міністрів України, однак 18 грудня 2018 р. прийнято рішення про поділ Державної фіскальної служби на Державну податкову і Державну митну служби.

Найбільша в Україні коаліція громадських організацій та експертів об'єдналися 3 метою вироблення консолідованої позиції експертної спільноти щодо необхідних для країни реформ і їх належного впровадження - Реанімаційного Пакету Реформ, метою якого $є$ підтримка та просування реформ для розбудови незалежної, демократичної, правової, сильної та авторитетної Української держави із заможним суспільством і рівними можливостями кожної особи на розвиток i самореалізацію, а також сприяння консолідації українського громадянського суспільства. Серед пріоритетів діяльності Реанімаційного Пакету Реформ декілька ключових напрямків: судова й антикорупційна реформи, децентралізація, реформа публічної адміністрації та правоохоронних органів, зміна виборчого законодавства, ключові трансформації в економіці, впровадження якісних змін у сфері публічних фінансів.

На реформування впливає значним чином співпраця Кабінету Міністрів із Міжнародним валютним фондом. Однак співпраця буває різною: з одного боку, зобов'язання, які уряд бере на себе у Меморандумі МВФ, сприяють більш оперативній роботі проурядових депутатів на користь змінам, з іншого - уряд інколи намагається йти шляхом найменшого супротиву: не стримує зростання нераціональних видатків держави, пропонуючи збільшувати податкове навантаження. Саме вирішення таких суперечностей й формувало рух у напрямку податкової реформи. 30 квітня 2014 р. МВФ ухвалив надання Україні нової позики Stand by обсягом 16,5 млрд дол. США. До кінця літа того ж року Україна отримувала транші, але оговорена у Меморандумі МВФ податкова реформа так і не стартувала. Прихід нового уряду після парламентських виборів 2014 р. надав можливість перезавантажити реформаторські зусилля [13].

11 березня 2015 р. Міжнародний валютний фонд ухвалив заміну програми Stand by на нову, чотирирічну програму Extended Fund Facility. Перший транш обсягом 5 млрд дол. США, за новою програмою EFF було отримано одразу після ії ухвалення. Надання другого траншу обсягом 1,7 млрд дол. США 
Права людини в Україні та у зарубіжних країнах: традиції та новації

було ухвалено Радою директорів Міжнародного валютного фонду 31 липня 2015 р.

Тож у 2015 р. стався серйозний підхід до податкової реформи. I вже 16 березня 2017 p. у Верховній Раді України був зареєстрований законопроект № 6201 «Про внесення змін до Податкового кодексу України щодо проведення податкової реформи та підвищення інвестиційної привабливості України» [23], метою якого була стабілізація фінансової ситуації, удосконалення та спрощення податкової системи, лібералізація податкового законодавства для стимулювання процесів економічного зростання вітчизняного виробництва зокрема та підвищення інвестиційної привабливості та конкурентоспроможності України на міжнародній арені загалом. Як зазначено у пояснювальній записці, законопроектом пропонувалося внесення низки змін до Податкового кодексу, якими передбачається:

- забезпечення стабільності податкового законодавства;

- зворотна дія в часі тільки для актів податкового законодавства України, якими вносяться зміни, доповнення, що передбачають пом'якшення або скасування відповідальності за порушення податкового законодавства;

- встановлення мораторію на внесення змін до податкового законодавства до 2020 р., окрім змін, які стосуються адміністрування та/або поліпшують становище платників податків, зборів;

- впровадження в національне податкове законодавство правил для оподаткування контрольованих іноземних компаній із метою боротьби з ухиленням від оподаткування, з податковим зловживанням при застосуванні податкових конвенцій, припинення відтоку капіталу 3 України та розмивання податкової бази;

- контролюючою особою пропонується визначити резидентів України - юридичних або фізичних осіб, котрі безпосередньо та/або опосередковано володіють корпоративними правами контрольованої іноземної компанії у розмірі 50 і більше відсотків; або частка такої участі в контрольованій іноземній компанії перевищує 10 відсотків, якщо частка участі всіх резидентів України в цій контрольованій іноземній компанії становить 50 і більше відсотків. При визначенні частки участі резидента-фізичної особи в 
Права людини в Україні та у зарубіжних країнах: традиції та новації

контрольованій іноземній компанії враховується як безпосередня його участь, так і опосередкована участь через його подружжя та/або неповнолітніх дітей;

- встановлення додаткових гарантій для платників податків у частині помилково та/або надміру сплачених грошових зобов'язань і пені, що виражається у визнанні сум помилково та/або надміру сплачених грошових зобов'язань, не повернутих платнику податків у порядку та строки, заборгованістю бюджету, на яку нараховується пеня на рівні 120\% облікової ставки НБУ, встановленої на момент виникнення пені, протягом строку її дії, включаючи день повернення грошових зобов'язань;

- подання податкової звітності до контролюючих органів в електронній формі з акцизного податку;

- скасування обмеження щодо застосування податкової консультації тільки особою, якій вона була надана, встановлення правил використання й іншими платниками податків податкових консультацій у разі відповідності умов, викладених у консультації, фактичним обставинам;

- запровадження вмотивованих податкових роз'яснень, що будуть надаватися центральним органом виконавчої влади, котрий реалізує державну фінансову політику, за зверненням платників податків і відображатимуть його офіційну позицію 3 питань правильності, повноти нарахування та сплати податків, зборів щодо здійснених господарських операцій або тих господарських операцій, здійснення яких планується у майбутніх звітних (податкових) періодах. Вмотивоване податкове роз'яснення, надане платнику податків, $\epsilon$ обов'язковим для контролюючих органів під час проведення перевірок, звірок;

- удосконалення інституту оскарження рішень контролюючих органів;

- лібералізація порядку проведення контролюючими органами перевірок та оформлення результатів таких перевірок.

Проте сьогодні зрозуміло, що проблеми податкової системи все ще залишаються найвагомішими серед перешкод для ведення бізнесу. Глибокі інституційні реформи податкової та митної служби розпочаті, але спрогнозувати результати поки що вкрай важко. Навіть податкова поліція продовжує своє фактичне існування, хоча і в невизначеному статусі. Не завершені реформи митної та фіскальної служб не дозволяють скоротити обсяги зловживань - контрабанди, порушення митних правил i 
Права людини в Україні та у зарубіжних країнах: традиції та новації

великомасштабної податкової оптимізації із застосуванням офшорів, які залишаються найбільшими «дірами» в податковій системі після ліквідації більшості «податкових ям», що дозволяли масово ухилятися від ПДВ. Позитивні результати спостерігаються тільки із мінімізацією схем по ухиленню від сплати ПДВ, у 2020 р. робота ДПС була ефективною по подоланню цих схем. Щодо офшорних схем, то у 2020 р. було прийнято низку деофшоризаційних норм, якими впроваджено: оподаткування контрольованих іноземних компаній; запобігання уникненню статусу постійного представництва й оподаткування постійних представництв; правило запобігання зловживанню чинними угодами про уникнення подвійного оподаткування; удосконалення норм стосовно документації із трансфертного ціноутворення; оподаткування «конструктивних дивідендів»; удосконалення правила «тонкої капіталізації» тощо, що має привести до мінімізації цих видів схем у наступні роки.

Одним із ключових недоліків податкової системи України все ще залишається застаріла модель оподаткування прибутку підприємств, яка $є$ дискреційною та створює значні корупційні ризики. Важливим $є$ реформування цього податку - найкращим варіантом $€$ заміна його інноваційним податком на виведений капітал, котрий суттєво спрощує адміністрування та стимулює інвестиції. Все ще надмірно високим залишається оподаткування праці, і це сприяє тінізації ринку праці.

На часі - продовження та подальше поглиблення податкової реформи, яка би сприяла захисту прав і законних інтересів платників податків, зробила би податкову систему простою та зрозумілою із розумними податковими ставками, що зацікавлять інвесторів як внутрішніх, так і зовнішніх, адже призначення податкової системи, яка $\epsilon$ складовою частиною економічної моделі розвитку країни, полягає не лише у збиранні податків і забезпеченні доходної частини бюджету для виконання державою своїх функцій, а й у сприянні досягненню стратегічної мети розвитку національної економіки.

Не можна сказати, що нічого не зроблено у цьому напрямку, адже в Україні розроблено законодавчу базу, яка регламентує справляння податків, створено адміністративні органи, що контролюють виконання законодавства суб'єктами господарювання, але, на жаль, необхідно визнати, що податкова система залишається не ефективною i не досягає свого функціонального призначення. На відміну від країн 
Права людини в Україні та у зарубіжних країнах: традиції та новації

Європейського Співтовариства, податкова система України не $є$ інструментом підвищення конкурентоспроможності держави, не сприяє зростанню економічної активності суб'єктів господарювання. Основна проблема української податкової системи полягає в надмірному навантаженні як на бізнес, так і на громадян [24].

Тож важливим чинником забезпечення економічної стабільності країни виступає здійснення ефективної податкової політики, яка насамперед повинна бути направлена на стимулювання економічного зростання та соціального розвитку, на одне зі стратегічних завдань держави - сприяння розвитку внутрішнього ринку товарів і послуг, підтримуючи та захищаючи права власного товаровиробника.

\section{3. Судова форма захисту порушених прав платників податків}

Конституційна реформа дала можливість громадянину почуватися рівним у відносинах із завжди всесильною і всеправою державою. Оскільки відносини між громадянином і державою регулюються Конституцією України, то при виданні законів та інших нормативних актів держава пов'язана конституційними нормами, насамперед - нормами про права i свободи людини. Видання акта, що порушує основні права i свободи, призводить за певних умов до виникнення спору про конституційність закону, тобто про його відповідність положенням Конституції.

Звернення до суду для захисту конституційних прав і свобод людини та громадянина безпосередньо на підставі Конституції України гарантується ст. 8 Конституції.

На початковому етапі діяльності Конституційного Суду (1991-1994) конфлікт між державою і людиною виникав переважно із приводу порушення трудових, житлових та інших соціальних прав. Після прийняття нової Конституції України 1996 р. Конституційний Суд дедалі більше став захищати право приватної власності, право на вільну підприємницьку діяльність і права громадян у сфері оподаткування. Швидше за все, ця зміна тенденцій виникла не випадково. Це результат того, що вперше в Українській історії серед найважливіших принципів, які становлять основи конституційного ладу України, названі принципи свободи економічної діяльності та соціальної держави. На фундамент цих конституційних принципів спираються економічні та соціальні права. 
У Конституції СРСР 1977 р. містилася глава 2 «Економічна система», в якій закріплювалися підвалини державної економіки. У Конституції України 1996 р. така глава відсутня. Це зовсім не означає, що для конституційного регулювання байдужі основи економічного ладу. Ні, в чинній Конституції основи економічного ладу визначені, але опосередковано - через права і свободи людини та громадянина.

Таким чином, принципово змінилося конституційне трактування підприємництва. Якщо раніше практично вся сфера економіки перебувала в руках держави, то нині підприємництво й економічні відносини трактуються через призму основних економічних прав, оскільки ст. 41 і 42 Конституції, котрі закріплюють право за на вільне підприємництво і право приватної власності, поміщені в розділ 2 Конституції «Права, свободи та обов'язки людини і громадянина». Зараз у сфері економіки пріоритетом володіють приватний підприємець і приватний власник. На конституційному рівні закріплено, що сфера економіки - це насамперед сфера приватного інтересу та приватної ініціативи, тобто сфера регулювання традиційно $\epsilon$ сферою приватного права.

Революційний ефект конституційних принципів не зводиться тільки до глибинних змін у сфері економічних відносин. Не менший вплив проявляють вони як соціальні відносини. Конституційні принципи, складові частини основи конституційного ладу, перебувають у системному взаємозв'язку. Не $\epsilon$ винятком і принципи свободи економічної діяльності та соціальної держави. Держава залишає сферу економіки, не веде в колишньому обсязі підприємницької діяльності, а питома вага державної власності внаслідок приватизації неухильно знижується. Тож виникає питання - чи може тепер людина розраховувати на те, щоб держава повністю могла взяти на себе турботу про неї, забезпечити всі ї̈ потреби?

Коли держава виступала як загальний роботодавець, вона активно займалася перерозподілом виробленого суспільного продукту за допомогою перерозподілу прибутку, одержуваного державними підприємствами, однак вона не була соціальною, бо нестримна мілітаризація економіки, низька продуктивність праці приводили до того, що витрати на соціальну сферу нараховувалися за так званим залишковим принципом, тобто, наприклад, спочатку витрати на оборону і космос, а вже потім на соціальні виплати. 
Проблема становлення правової держави постійно привертала і привертає увагу багатьох дослідників. Ї̈̈ формування, а також демократизація сучасного суспільства припускають наявність економічної та політичної свободи як основи соціального прогресу i розвитку таких суспільних відносин, які би сприяли i забезпечували захист прав людини і громадянина, держави та муніципальних утворень, господарюючих та інших суб'єктів. Необхідно відзначити, що економічна і політична ситуація, яка швидко змінюється за сучасних умов, ставить іноді учасників правовідносин у скрутне становище, оскільки система ринку підпорядковується правилам ззовні.

Україна зробила вибір на користь ринкових реформ, демократії та правової держави, тому подальший іiі розвиток створив якісно нові суспільні відносини, які визначаються новим співвідношенням права, економіки та держави.

Сьогодні найважливіші функції ринку реалізуються внаслідок взаємодії всіх суб'єктів, котрі керуються своїми інтересами (публічними, приватними). I для того, щоб таке прагнення кожного не створювало безладності, не порушувало підвалин суспільства, моралі, систему цінностей, створюються правила функціонування ринку, а також регулювання суспільних відносин, дотримання яких у необхідних випадках забезпечується примусовою силою держави. Ці норми лежать в основі законодавчої та судової практики, вони засновані на чіткому дотриманні принципу законності, неприпустимості нехтування вимогами цивілізованого суспільства, а також надання певних гарантій.

Орієнтація нашої країни на формування правової держави призвела до переоцінки пріоритетів, визнання загальнолюдських цінностей, зміни правового статусу органів державної влади, місцевого самоврядування, комерційних i некомерційних організацій, правового положення громадян.

Тенденції, що склалися у суспільстві, виражаються у суперечностях між органами публічної влади та приватними суб'єктами, висуваються сьогодні на перший план. Конфліктність відносин породжує кризові явища політичного, економічного і соціального характеру. У зв'язку з цим у країні активно проходить багатопрофільна реформа, складовою частиною якої $\epsilon$ адміністративна реформа, реформа податкової та фінансової систем. 
Адміністративна реформа характеризується створенням нових органів виконавчої влади та скасуванням наявних, а також зміною їх компетенції. Додатковим стимулом до підготовки та проведення цієї реформи, що має на меті зробити публічне управління адекватним потребам демократії та ринкової економіки, стали суттєві зрушення в економічній сфері, зумовлені насамперед появою у промисловому секторі домінуючого числа суб'єктів приватного права, а також зміна системи поглядів на роль держави в управлінні.

Сучасний розвиток суспільних відносин, обтяжений рішенням проблем, пов'язаних із виходом зі світової фінансово-економічної кризи, змушує переглянути роль фінансових інститутів у нашій державі й у світі, по-новому поглянути на нормотворчу та правозастосовчу діяльність.

За цих умов особливого значення набуває наука фінансового права і законодавство, що регулює суспільні відносини у сфері акумулювання, розподілу, перерозподілу і використання фондів грошових коштів у банківській системі, а також у сфері здійснення державного фінансового контролю, який охоплює різні сторони діяльності суспільства, у т. ч. функціонування таких необхідних нині важелів, як публічні фінанси.

Говорячи про побудову ефективної економічної моделі, важливо звернути увагу на захист прав платників податків, на дотримання податкової дисципліни, які і $\epsilon$ запорукою цієї ефективності.

Практика показує, що платники податків із більшою готовністю виконують свої податкові зобов'язання перед державою, коли чинна в такій державі система правового регулювання передбачає механізми, які забезпечують як відновлення прав платників податків у разі їх порушення, так і залучення до відповідальності держави та ії посадових осіб за порушення закону. Ці механізми мають не просто існувати на папері, а бути працюючими й ефективними. Центральною ідеєю адміністративного та судового механізмів оскарження рішень контролюючих органів у сфері оподаткування $\epsilon$ забезпечення захисту прав платників податків від неправомірних рішень, дій (бездіяльності) контролюючих органів.

Серед безлічі змін і новацій, внесених Законом України «Про внесення змін до Податкового кодексу України щодо вдосконалення адміністрування податків, усунення технічних та логічних неузгодженостей у податковому законодавстві» № 466 
Права людини в Україні та у зарубіжних країнах: традиції та новації

до Податкового кодексу, $\epsilon$ такі, що стосуються податкових правопорушень податкових органів і шкоди, яку платникам завдають податкові органи своїми рішеннями, діями чи бездіяльністю.

До внесення змін вищеназваним Законом у Податковому кодексі України була прописана норма, котра певним чином давала платникам сподівання, що шкоду, завдану неправомірними діями податківців, буде відшкодовано. Так, у Податковому кодексі зазначено, що шкода, завдана платнику податків неправомірними рішеннями, діями чи бездіяльністю посадової або службової особи контролюючого органу, відшкодовується за рахунок коштів державного бюджету, передбачених для фінансування цього органу, незалежно від вини цієї особи (п. 21.3).

На практиці звернення до цієї норми платниками податків і через суд відстоювання свого права на відшкодування шкоди робилися багато разів. Загалом у реєстрі судових рішень можна знайти рішення про відшкодування платникам шкоди, але їх небагато, тож широко популярним із погляду практики застосування такої норми не стало [25].

Крім того, деякої неоднозначності у регулюванні питання щодо відшкодування шкоди додавав той факт, що у п. 21.3 йдеться лише про шкоду, заподіяну неправомірними рішеннями, діями чи бездіяльністю посадових (службових) осіб, а не самого контролюючого органу. Хоча, із правового погляду, права й обов'язки виникають між платниками податків і контролюючим органом, а не його посадовими особами. Тобто ухвалюють рішення та вчиняють дії (допускають бездіяльність) щодо платників саме контролюючі органи, а не їх посадові (службові) особи. Отже, платникам певним чином простіше та швидше було б отримувати відшкодування шкоди, якби в Податковому кодексі прямо йшлося про шкоду, заподіяну контролюючим органом.

Для врегулювання питання щодо відшкодування шкоди, заподіяної протиправними рішеннями, діями чи бездіяльністю контролюючих органів, ст. 114 викладено в новій редакції та 3 новим змістом.

Відповідно до п. 114.1 цієї статті особа, чиї права та/або законні інтереси порушено, має право на відшкодування шкоди, заподіяної протиправними рішеннями, діями чи бездіяльністю контролюючих органів, їх посадових (службових) осіб. 
Шкода, заподіяна протиправними рішеннями, діями чи бездіяльністю контролюючих органів, їх посадових (службових) осіб, відшкодовується державою за рахунок коштів державного бюджету незалежно від вини контролюючого органу, його посадових (службових) осіб.

Отже, по суті, новий п. 114.1 Податкового кодексу практично ідентичний п. 21.3 Податкового кодексу, який, до речі, не виключено з кодексу, тобто з моменту набуття чинності ст. 114 Податкового кодексу паралельно чинним $\epsilon$ і п. 21.3.

Між цими пунктами різниця лише в такому:

- у п. 114.1 ідеться не просто про «платників», як у п. 21.3, а про будь-яку особу, права якої порушено;

- $\quad$ п. 114.1 передбачає відшкодування шкоди не лише через неправомірні дії посадових (службових) осіб, а й самого податкового органу.

П. 114.2 Податкового кодексу передбачає, що шкода, заподіяна протиправними рішеннями, діями чи бездіяльністю контролюючих органів, їх посадових (службових) осіб, які визнаються податковими правопорушеннями відповідно до Кодексу, відшкодовується в повному обсязі в порядку, передбаченому законодавством про відшкодування шкоди.

Особа, чиї права порушені, за наявності обставин, передбачених п. 128.2 ст. 128 Податкового кодексу, має право заявити вимоги про відшкодування шкоди, заподіяної протиправними рішеннями, діями чи бездіяльністю контролюючих органів, їх посадових (службових) осіб, у розмірі однієї мінімальної заробітної плати, встановленої станом на дату визнання таких рішень, дій чи бездіяльності незаконними, у порядку, передбаченому законодавством. У такому разі доведенню підлягає лише протиправність рішень, дій чи бездіяльності стосовно особи.

У передбачених абзацом другим цього пункту випадках шкода понад встановлений розмір відшкодуванню не підлягає.

Отже, за загальним правилом розмір шкоди, на відшкодування якої має право претендувати особа, не обмежено зовсім, тобто шкода підлягає відшкодуванню в повному обсязі.

Таким чином, законодавці вирішили уточнити, що шкода підлягає відшкодуванню в повному обсязі в тому разі, якщо ії було заподіяно діями податківців, які визнаються податковими правопорушеннями. 
Права людини в Україні та у зарубіжних країнах: традиції та новації

Визначення податкових правопорушень контролюючих органів знаходимо в новому п. 128.1 Податкового кодексу України, відповідно до якого такими правопорушеннями потрібно вважати протиправні рішення, дії або бездіяльність контролюючих органів, їх посадових (службових) осіб, вчинення яких $€$ підставою для відшкодування шкоди особі, чиї права порушено, відповідно до закону.

Податковими порушеннями, відшкодування шкоди за вчинення яких згідно 3 п. 114.2 ст. 114 Кодексу допускається внаслідок доведення лише факту його вчинення, $€$ :

- прийняття незаконного рішення, а так само вчинення незаконних діянь (дій або бездіяльності) контролюючим органом та/або його посадовими (службовими) особами, що призвели до безпідставної відмови в набутті, а так само до безпідставної втрати особою статусу платника податку або платника одного з податків, набуття та/або анулювання (втрата) якого відбувається за рішенням контролюючого органу;

- невнесення або несвоєчасне внесення контролюючим органом даних до Реєстру заяв про повернення суми бюджетного відшкодування та/або порушення строків початку проведення камеральної перевірки, передбаченої п. 200.10 ст. 200 Кодексу, а у випадках, визначених п. 200.11 ст. 200 цього Кодексу, перевірки, зазначеної у такому пункті, якщо за результатами таких протиправних діянь було порушено строки повернення сум бюджетного відшкодування;

- прийняття посадовими (службовими) особами контролюючого органу рішення про використання майна, визначеного п. 87.3 ст. 87 Податкового кодексу, як джерела погашення грошового зобов'язання або податкового боргу платника податків;

- перешкоджання посадовими (службовими) особами контролюючого органу звільненню майна особи з-під режиму тимчасового затримання;

- незаконне застосування посадовими (службовими) особами контролюючого органу арешту майна або коштів на рахунках;

- безпідставне внесення посадовими (службовими) особами контролюючого органу даних про наявність податкового боргу платника податків або несвоєчасне внесення чи невнесення даних про відсутність податкового боргу платника податків. 
Отже, усі протиправні рішення, дії або бездіяльність контролюючих органів і їх посадових (службових) осіб, учинення яких $\epsilon$ підставою для відшкодування шкоди відповідно до закону, $є$ податковими правопорушеннями податківців.

Про відшкодування шкоди зазначено у Цивільному кодексі України. Так, за змістом ст. 1173, 1174 Цивільного кодексу шкоду, завдану фізичній або юридичній особі незаконними рішеннями, дією чи бездіяльністю органу державної влади, органу влади Автономної Республіки Крим або органу місцевого самоврядування чи посадовою особою відповідного органу під час здійснення ними своїх повноважень, відшкодовує держава, Автономна Республіка Крим або орган місцевого самоврядування незалежно від вини цих органів чи посадової особи.

Ст. 1173 та 1174 Цивільного кодексу $\epsilon$ спеціальними та передбачають певні особливості, характерні для розгляду справ про деліктну відповідальність органів державної влади та посадових осіб, які відмінні від загальних правил деліктної відповідальності. Так, зокрема, цими правовими нормами передбачено, що для застосування відповідальності посадових осіб та органів державної влади наявність їх вини не $\epsilon$ обов'язковою. I ця умова збігається з умовою, передбаченою положеннями Податкового кодексу. Утім, ці норми не заперечують обов'язкової наявності інших елементів складу цивільного правопорушення, які $\epsilon$ обов'язковими для доказування у спорах про стягнення збитків.

Наведене означає, що відповідно до норм Цивільного кодексу необхідною підставою для притягнення органу державної влади до відповідальності у вигляді стягнення шкоди $\epsilon$ наявність трьох умов: неправомірних дій цього органу, наявності шкоди та причинного зв'язку між неправомірними діями й заподіяною шкодою. Крім того, потрібно підтвердити факт порушення права та/або інтересів особи. Довести наявність цих умов має позивач, який звернувся з позовом до суду про стягнення шкоди на підставі ст. 1173, 1174 Цивільного кодексу України.

Отже, можемо дійти висновку, що податковими правопорушеннями контролюючих органів $\epsilon$ їхні рішення, дії або бездіяльність, які:

-є неправомірними;

- завдають шкоду особі,

- порушують права та/або інтереси особи; 
Права людини в Україні та у зарубіжних країнах: традиції та новації

- характеризуються наявністю причинного зв'язку між шкодою та неправомірними діями.

За умови доведення наявності вказаних вище обставин рішення, дії або бездіяльність контролюючих органів будуть податковими правопорушеннями, а шкода, заподіяна такими правопорушеннями, підлягатиме відшкодуванню з бюджету в повному обсязі в судовому порядку.

\section{Висновки}

За сучасних умов трансформації Конституція України повинна не тільки виражати ідеї поділу влади як фундаментального принципу демократичної організації держави, а й стати на захист основних прав людини та бути безумовним символом єдності Українського народу на шляху утвердження статусу держави як процвітаючої й успішної держави у світі. Захист прав і законних інтересів платників податків як важлива складова частина захисту прав людини має стати пріоритетом у діяльності держави.

Під захистом прав платників податків слід розуміти, з одного боку, систему юридичних і організаційних гарантій дотримання встановлених національним правом прав і законних інтересів платників, функціонування яких покликано забезпечити співмірність обмеження прав конкретного платника та інтересів всього суспільства чи елемент юридичної податкової конфліктності. 3 іншого - конкретні дії учасників податкових відносин, у т. ч. конфліктних, їх представників, спрямовані на забезпечення власних інтересів у процесі розгляду податкових спорів.

Аналіз податкового законодавства та практика його застосування показує, що останнім часом у сфері захисту прав платників податків відбулися значні зміни. Насамперед вони зумовлені прийняттям Податкового кодексу України, який на законодавчому рівні закріпив систему органів, що здійснюють захист прав платників податків.

За умов формування нової моделі економічного розвитку Україна поступово йде шляхом реформування як податкової системи держави загалом, так і правових механізмів конкретних податків і зборів, адже провідну роль у формуванні доходів бюджетної системи України виконують податкові платежі.

Досліджуючи судову форму захисту порушених прав платників податків, ми встановили, що на рівні кодифікованого акта - Податкового кодексу, прямо визначено, що платники можуть отримати відшкодування не лише шкоди, заподіяної 
Права людини в Україні та у зарубіжних країнах: традиції та новації

неправомірними діями посадових осіб податкових органів, а й шкоди, заподіяної неправомірними діями самих податкових органів. Відшкодування шкоди здійснюють за кошти держави та без доведення вини податківців.

Для отримання відшкодування шкоди у повному обсязі платникам потрібно довести протиправність дій податківців, факт порушення прав, наявність шкоди та причинний зв'язок між шкодою і протиправними діями податківців.

У визначених Податковим кодексом випадках платники за власним бажанням можуть отримати відшкодування шкоди не в повному обсязі, а в розмірі однієї мінімальної заробітної плати. У такому разі достатньо буде лише самого факту протиправності рішень чи дій (бездіяльності) податківців.

\section{Список використаних джерел:}

1. Марущак А.В., Олексій У.О. Науково-нормативні підходи до визначення податкової політики. Юридичний вісник. 2021. № 1. С. 101-108.

2. Міжнародний пакт про громадянські і політичні права від 16 грудня 1966 р. URL: https://zakon.rada.gov.ua/laws/ show/995_043\#Text (дата звернення 15.04.2021).

3. Кармаліта М.В. Приватний і публічний інтерес у системі податкових правовідносин : монографія. Хмельницький : ФОП Мельник А.А., 2019. 328 с.

4. Конституція України, прийнята на п’ятій сесії Верховної Ради України 28 червня 1996 р. URL: https://zakon.rada.gov.ua/ laws/show/254\%D0\%BA/96-\%D0\%B2\%D1\%80\#top (дата звернення 15.04.2021).

5. Шемшученко Ю.С. Конституційний процес у незалежній Україні (до 20-річчя Конституції України. Конституційний полілог. 20 років Конституції України: суспільство і влада в конституційному процесі. Збірка тез міжнародної науковопрактичної конференції. Київ : BAITЕ, 2016. 400 с.

6. Конституція України. Науково-практичний коментар / редкол. : В.Я. Тацій, О.В. Петришин, Ю.Г. Барабаш та ін. ; Нац. акад. прав. наук України. Харків : Право, 2011. 1128 с.

7. Словарь иностранных слов / отв. ред. В.В. Бурцева, Н.М. Семенова. Москва, 2007. 819 с.

8. Велика українська юридична енциклопедія : у 20 т. Т. 3 : Загальна теорія права. Харків : Право, 2017. 952 с. 
Права людини в Україні та у зарубіжних країнах: традиції та новації

9. Дудина Н.В. Механизм защиты прав налогоплательщика. Налоги и налогообложение. 2005. № 6.

10. Козлов Н.А. Средства и способы защиты прав налогоплательщика при осуществлении налогового контроля. Вестник Воронежского государственного университета. Серия : Право. 2015. № 3 (22). С. 175-187.

11. Національна стратегія у сфері прав людини. Указ Президента України від 24 березня 2021 р. № 119/2021.

12. Про Антимонопольний комітет України. Закон України від 26 листопада 1993 р. № 3659-XII. (дата звернення 16.04.2021).

13. Податковий кодекс України від 2 грудня 2010 р. № 2755 VI. Дата звернення 17.04.2021.

14. Іванов Ю.Б., Крисоватий А.І., Десятнюк О.М. Податкова система. Київ : Атіка, 2006. 920 с.

15. Кучеров И.И. Налоговое право: курс лекций. Москва : АО «Центр ЮрИнфоР», 2006. 448 с.

16. Кучерявенко Н.П. Налоговое право Украины : учебное пособие. Симферополь : 000 «Фирма «Салта» ЛТД», 2012. 476 с.

17. Воронова Л.К. Финансовое право : учебное пособие. Харьков : Легас, 2003. 360 с.

18. Пепеляев С.Г. Налоговое право : учебник. Москва : Юристь, 2003. 591 с.

19. Кучерявенко Н.П. Курс налогового права : в 2 т. Т. 1: Общая часть / под ред. Д.М. Щекина. Москва : Статут, 2009. 863 с.

20. Финансовое право : учебное пособие / отв. ред. И.В. Рукавишникова. Москва : Норма, 2007. 510 с.

21. Стратегія сталого розвитку «Україна - 2020»: Указ Президента України від 12 січня 2015 р. № 5/2015.

22. URL: http://reformsguide.org.ua/ua/analytics/tax-reform-2/ (дата звернення: 20.04.2021).

23. Про внесення змін до Податкового кодексу України щодо проведення податкової реформи та підвищення інвестиційної привабливості України. Проект Закону № 6201. URL: http://w1.c1.rada.gov.ua/pls/zweb2/webproc4_1?pf3511=6135 5 (дата звернення: 20.04.2021).

24. Латковська Т.А. Проблеми реформування податкової системи України. Наукові праці Національного університету «Одеська юридична академія». Т. XXII. 2018. С. 62-71.

25. Єфімов С. Як податкові органи відповідатимуть за шкоду. URL: https://bz.ligazakon.ua/ua/magazine_article/BZ012454 (дата звернення: 20.04.2021). 